\title{
Pengaruh Bahan Organik Nabati dan Hewani terhadap Pertumbuhan Protocorm Like Bodies Phalaenopsis amabilis (L.) Blume
}

\author{
The Effect of Plant and Animal Organic Compounds on Protocorm Like Bodies \\ Growth of Phalaenopsis amabilis (L.) Blume
}

\author{
Yustia Yulianti ${ }^{1}$, Syarifah Iis Aisyah ${ }^{2}$, dan Dewi Sukma ${ }^{2 *}$
}

Diterima 10 Agustus 2016/Disetujui 9 November 2016

\begin{abstract}
Phalaenopsis orchid is among the popular ornamental plants in Orchidaceae family. Clonal propagation of this orchid is usually performed through protocorm like bodies (plbs) multiplication in tissue culture medium. The objective of this experiment was to determine the effect of the combination of phyto-organic substances (bananas, potatoes, sweet potatoes extract) and fish emulsion on in vitro growth, multiplication of plbs and plantlet regeneration of Phalaenopsis amabilis. This experiment was arranged in completely randomized design with two factors. The first factor was phyto-organic substances which consisted of bananas, potatoes, and sweet potatoes extract $\left(50 \mathrm{~g} \mathrm{~L}^{-1}\right)$ and the second one was fish emulsion with four concentration levels $\left(0 \mathrm{ml} \mathrm{L}^{-1}, 2 \mathrm{ml} \mathrm{L}{ }^{-1}, 4\right.$ $m l L^{-1}$, and $6 \mathrm{ml} \mathrm{L}{ }^{-1}$ ). Basic (control) medium used NPK fertilizer $\left(2 \mathrm{~g} \mathrm{~L}^{-1}\right)$ with addition of $M S$ vitamins, myo-inositol, $1.5 \%$ of coconut water, and $2 \mathrm{~g} \mathrm{~L}^{-1}$ of active charcoal. The results showed that the highest survival rate (>90\%) and multiplication (>70\%) of plbs was found on control medium with addition of $2 \mathrm{ml} \mathrm{L}^{-1}$ of fish emulsion or banana or potato extract without fish emulsion. The best plantlet morphogenesis as indicated by leaf and root number, was resulted on medium with addition of potato extract without fish emulsion which produced 3.2 leaves and 2.2 roots per plantlets. The best plantlet morphogenesis as indicated by leaf and root number, was resulted on medium with addition of potato extract without fish emulsion which produced 3.2 leaves and 2.2 roots per plantlets. The result of this experiment suggested that basic medium with addition of $2 \mathrm{ml}$ $L^{-1}$ of fish emulsion, banana or potato extract was appropriate for plbs growth and multiplication while basic medium with addition of potato extract without fish emulsion for plantlet regeneration.
\end{abstract}

Keywords: bananas, fish emulsion, potatos, protocorm like bodies (plbs), sweet potatoes

\begin{abstract}
ABSTRAK
Anggrek Phalaenopsis merupakan salah satu tanaman hias paling populer dalam famili Orchidaceae. Perbanyak klonal anggrek ini biasanya dilakukan melalui multiplikasi protocorm like bodies (plbs) dalam kultur in vitro. Penelitian ini bertujuan untuk mengetahui pengaruh kombinasi bahan organik nabati (ekstrak pisang, kentang, ubi jalar) dan emulsi ikan terhadap pertumbuhan, multiplikasi plbs dan regenerasi planlet Phalaenopsis amabilis. Percobaan disusun dalam rancangan acak lengkap dengan dua faktor perlakuan. Faktor pertama adalah bahan organik nabati terdiri atas ekstrak pisang, kentang, dan ubi jalar sebanyak $50 \mathrm{~g} \mathrm{~L}^{-1}$ dan faktor kedua adalah emulsi ikan dengan empat konsentrasi yaitu 0, 2, 4 atau $6 \mathrm{ml} \mathrm{L}^{-1}$. Media dasar (kontrol) menggunakan pupuk NPK $\left(2 \mathrm{~g} \mathrm{~L}^{-1}\right)$ ditambah dengan vitamin dan myoinositol dari media Murashige dan Skoog (MS), 15\% air kelapa dan $2 \mathrm{~g} \mathrm{~L}^{-1}$ arang aktif. Hasil penelitian menunjukkan bahwa keberhasilan hidup tertinggi (>90\%) dan multiplikasi plbs tertinggi (sekitar 70\%) ditemukan pada media kontrol yang ditambahkan emulsi ikan $2 \mathrm{ml} \mathrm{L}^{-1}$ atau ditambahkan ekstrak pisang atau kentang tanpa penambahan emulsi ikan. Morfogenesis plbs menjadi planlet yang terbaik sebagaimana ditunjukkan oleh jumlah daun dan akar

\footnotetext{
${ }^{1}$ Mahasiswa Program Sarjana Departemen Agronomi dan Hortikultura, Fakultas Pertanian, Institut Pertanian Bogor

${ }^{2}$ Staf Pengajar Departemen Agronomi dan Hortikultura, Fakultas Pertanian, Institut Pertanian Bogor (Bogor Agricultural University)

Jl. Meranti, Kampus IPB Darmaga, Bogor 16680, Indonesia Telp.\& Faks. 62-251-8629353

Email: dsukma70@gmail.com (*penulis korespondensi)
} 
terbanyak dihasilkan pada perlakuan ekstrak kentang tanpa emulsi ikan dengan jumlah daun dan akar yang dihasilkan adalah sebanyak 3.2 helai daun dan 2.2 akar. Hasil penelitian ini menunjukkan bahwa media dasar yang ditambah dengan $2 \mathrm{ml} \mathrm{L}^{-1}$ emulsi ikan, ekstrak pisang atau kentang adalah sangat sesuai untuk pertumbuhan dan multiplikasi plbs sementara media dasar yang ditambah ekstrak kentang tanpa emulsi ikan terbaik untuk regenerasi planlet.

Kata kunci: emulsi ikan, kentang, pisang, protocorm like bodies (plbs), ubi jalar

\section{PENDAHULUAN}

Anggrek merupakan salah satu jenis tanaman hias yang banyak diminati dan memiliki nilai ekonomis tinggi. Salah satu anggrek penting di Indonesia adalah genus Phalaenopsis. Anggrek bulan (Phalaenopsis amabilis) merupakan salah satu anggrek kebanggaan nasional. Anggrek Phalaenopsis amabilis merupakan salah satu bunga nasional Indonesia dengan sebutan Puspa Pesona. Anggrek tersebut memiliki ciri khas bunga berwarna putih bersih dengan lidah kuning keemasan (Rukmana, 2000). Perbanyakan anggrek monopodial seperti Phalaenopsis secara konvensional dapat dilakukan menggunakan keiki yang muncul dari tangkai bunga. Perbanyakan secara konvensional sangat lambat prosesnya, sehingga tidak dapat diandalkan untuk memproduksi bibit secara massal jika dibutuhkan klon anggrek tertentu dalam jumlah besar (Yusnita et al., 2007). Salah satu teknik yang bisa dilakukan adalah dengan teknik kultur in vitro. Kultur in vitro merupakan salah satu metode untuk melakukan perbanyakan tanaman pada kondisi yang aseptik. Induksi jumlah protocorm like bodies (plbs) dengan menggunakan protocorm anggrek hasil silangan yang dikecambahkan merupakan salah satu cara dalam teknik kultur jaringan tanaman yang dilakukan untuk memperbanyak beberapa jenis anggrek Phalaenopsis (Nazi, 2014). Plbs merupakan pertumbuhan lebih lanjut dari embrio anggrek. Menurut Yusnita et al. (2007), plbs yang terbentuk mula-mula berukuran kecil (1-2 $\mathrm{mm}$ ) berbentuk globular dan berwarna hijau muda. Pada tahap perkembangan lebih lanjut, plbs akan tumbuh planlet yang lengkap dengan daun dan akar.

Faktor-faktor yang mempengaruhi pertumbuhan dan perkembangan sel pada kultur in vitro diantaranya sumber eksplan, media, hormon, zat pengatur tumbuh (ZPT), dan lingkungan fisik kultur (Sandra, 2012).
Media kultur yang baik tidak hanya mendukung kehidupan jaringan tapi aktif merangsang pertumbuhan dan proliferasi sel secara in vitro sehingga tidak hanya dapat menunjang eksplan tetapi juga meningkatkan pertumbuhannya secara optimal (Semiarti et al., 2010). Jenis media dan kandungan unsur hara yang digunakan sangat berpengaruh terhadap kecepatan pertumbuhan tanaman (Niedz dan Evans, 2007). Salah satu komponen yang umumnya ditambahkan dalam media kultur yaitu bahan organik. Berdasarkan beberapa penelitian sebelumnya seperti yang dilakukan oleh Agriani (2010) dan Dwiarum (2007), modifikasi media kultur dengan penambahan bahan organik mampu meningkatkan viabilitas anggrek. Berdasarkan penelitian Putri (2015), selain penggunaan media dasar yang sesuai, bahan organik tertentu juga dapat memacu pertumbuhan, perkembangan, dan ketahanan tanaman terhadap penyakit.

Menurut Kasutjianingati dan Irawan (2013), penambahan BAP $2 \mathrm{mg} \mathrm{L}^{-1}$, air kelapa $150 \mathrm{ml} \mathrm{L}^{-1}$ dan ekstrak pisang ambon $50 \mathrm{~g} \mathrm{~L}^{-1}$ memberikan pengaruh sama pada penambahan jumlah tunas, rata-rata 2 tunas anggrek bulan Phalaenopsis amabilis. Selain itu, menurut Sallolo et al. (2012), penambahan ekstrak pisang memberikan pengaruh yang nyata hampir terhadap seluruh peubah pengamatan planlet anggrek Dendrobium Candy Stripe Lasianthera umur 16 MST yaitu tinggi planlet, luas daun, jumlah akar, panjang akar, jumlah anakan, bobot basah dan bobot kering, kecuali terhadap jumlah daun berpengaruh tidak nyata. Agriani (2010) menyatakan bahwa perlakuan ekstrak ubi jalar $300 \mathrm{~g} \mathrm{~L}^{-1}$ memberikan hasil optimal terhadap saat muncul akar, jumlah daun, dan jumlah akar sedangkan perlakuan emulsi ikan $2 \mathrm{ml} \mathrm{L}^{-1}$ memberikan hasil optimal terhadap saat muncul akar serta perlakuan emulsi ikan $4 \mathrm{ml} \mathrm{L}^{-1}$ memberikan hasil optimal terhadap tinggi plantlet, jumlah daun, dan panjang akar plbs anggrek persilangan 
Phalaenopsis Pinlong Cinderella $x$ Vanda tricolor. Raynalta dan Sukma (2013) melaporkan bahwa keberhasilan hidup plbs Phalaenopsis amabilis paling tinggi diperoleh dalam media dengan media dasar pupuk NPK (20:20:20) yang ditambahkan air kelapa $15 \%$. Penelitian ini bertujuan untuk mengetahui pengaruh kombinasi bahan organik nabati dan hewani terhadap pertumbuhan dan multiplikasi plbs serta regenerasi planlet Phalaenopsis amabilis.

\section{METODE PENELITIAN}

Penelitian dilaksanakan pada bulan Maret sampai Juli 2016, bertempat di Laboratorium Kultur Jaringan, Departemen Agronomi dan Hortikultura, Fakultas Pertanian, Institut Pertanian Bogor. Bahan tanaman yang digunakan dalam penelitian ini adalah clump plbs anggrek Phalaenopsis amabilis yang diperoleh dari semaian biji yang sebelumnya sudah dikulturkan selama 8 bulan pada setengah konsentrasi media Murashige dan Skoog (1962) (MS1/2) yang ditambahkan $15 \%$ air kelapa.

Rancangan percobaan yang digunakan pada percobaan ini adalah rancangan faktorial dengan dua faktor yang disusun dalam Rancangan Acak Lengkap (RAL). Faktor pertama adalah perlakuan bahan organik tambahan disamping air kelapa $150 \mathrm{ml} \mathrm{L}^{-1}$ yang sudah ada di media dasar yaitu tanpa penambahan bahan organik, penambahan ekstrak pisang ambon, ekstrak kentang dan ekstrak ubi jalar dengan konsentrasi masingmasing $50 \mathrm{~g} \mathrm{~L}^{-1}$. Faktor kedua adalah emulsi ikan (merk Liquinox) dengan 4 taraf konsentrasi yaitu tanpa emulsi ikan, emulsi ikan 2, 4 atau $6 \mathrm{ml} \mathrm{L}^{-1}$. Kombinasi dua faktor tersebut menghasilkan 16 kombinasi perlakuan yang masing-masing diulang sebanyak $3 \mathrm{kali}$, sehingga terdapat 48 satuan percobaan. Setiap satuan percobaan terdiri atas 5 botol dan setiap botol terdiri dari $5 \mathrm{plbs}$, sehingga total terdapat 1200 plbs yang digunakan dalam percobaan. Peubah pertumbuhan yang diamati adalah persentase plbs yang hidup, persentase kontaminasi, persentase plbs bermultiplikasi, jumlah daun, dan jumlah akar planlet. Pengamatan dilakukan dua minggu sekali. Data yang diperoleh dari hasil pengamatan dianalisis dengan uji sidik ragam pada taraf $\alpha=$
5\% menggunakan software STAR 2.0.1 dan SAS 9.1.3 portable. Jika hasil uji sidik ragam yang berpengaruh nyata, maka dilakukan uji lanjut dengan uji Duncan Multiple Range Test (DMRT).

Pembuatan media dasar dilakukan dengan melarutkan $2 \mathrm{~g} \mathrm{~L}^{-1}$ pupuk lengkap $(\mathrm{N}: \mathrm{P}: \mathrm{K}=20: 20: 20)$ ditambahkan $30 \mathrm{~g} \mathrm{~L}^{-1}$ gula pasir, $150 \mathrm{ml} \mathrm{L}^{-1}$ air kelapa, dan $2 \mathrm{~g} \mathrm{~L}^{-1}$ arang aktif. Ekstrak bahan organik nabati pisang, kentang dan ubi jalar sebelum ditambahkan ke media terlebih dahulu diblender sampai halus dan disaring lalu ditambahkan ke media dasar sesuai perlakuan. Emulsi ikan ditambahkan ke dalam larutan media sesuai perlakuan. Selanjutnya larutan media diletakkan pada magnetic stirrer agar larutan homogen dan diukur $\mathrm{pH}$ hingga mencapai 5.8, apabila $\mathrm{pH}$ lebih kecil dari 5.8 dilakukan penambahan $\mathrm{KOH} 1 \mathrm{~N}$ atau dilakukan penambahan $\mathrm{HCl} 1$ $\mathrm{N}$ jika $\mathrm{pH}$ diatas 5.8. Larutan dimasukkan ke dalam panci dan ditambahkan agar sebanyak 7 $\mathrm{g} \mathrm{L}^{-1}$, lalu diaduk hingga mendidih, lalu dituang kedalam botol kultur sebanyak $25 \mathrm{ml}$. Botol kultur ditutup dengan plastik dan diikat dengan karet gelang serta diberi label. Botol yang telah terisi media disterilisasi dengan autoklaf pada suhu $121{ }^{\circ} \mathrm{C}$ dengan tekanan 17.5 psi selama 20 menit. Penanaman dilakukan di dalam laminar yang telah disterilkan dengan alkohol 70\%. Clump plbs disubkultur dari media sebelumnya ke media perlakuan. Kultur plbs diinkubasi di laboratorium yang diberi cahaya dari lampu fluorescent dengan intensitas cahaya 10002000 lux. Ruang kultur dilengkapi dengan pendingin ruangan yang suhunya berkisar 24$30{ }^{\circ} \mathrm{C}$.

\section{HASIL DAN PEMBAHASAN}

Media dalam kultur in vitro merupakan salah satu faktor penentu keberhasilan perbanyakan dan perkembangan tanaman selain faktor eksplan dan lingkungan tumbuh (Sallolo et al., 2012). Hal tersebut juga didukung laporan Semiarti et al. (2010) dimana medium kultur yang baik tidak hanya mendukung kehidupan jaringan tapi aktif merangsang pertumbuhan dan proliferasi secara in vitro sehingga tidak hanya dapat menunjang eksplan tetapi juga meningkatkan pertumbuhannya secara optimal. Jenis media 
dan kandungan unsur hara yang digunakan sangat berpengaruh terhadap kecepatan pertumbuhan tanaman (Niedz dan Evans, 2007).

Perbanyakan anggrek Phalaenopsis umumnya dilakukan dengan cara perkecambahan biji secara in vitro, dimana benih anggrek yang ditanam pada media membentuk plbs, selanjutnya plbs akan beregenerasi membentuk planlet atau kemungkinan juga membentuk plbs sekunder. Pertumbuhan plbs menjadi planlet atau membentuk plbs sekunder dipengaruhi oleh genetik dan komposisi media (Andini, 2013). Pada percobaan ini perkembangan plbs yang dikulturkan menunjukkan terjadinya multiplikasi pada semua media perlakuan. Multiplikasi terjadi selama 6-10 MST dengan munculnya bulatan-bulatan yang bergerombol di sekitar plbs induk. Perkembangan selanjutnya yaitu terbentuknya daun pada saat plbs berumur 4 MST dan terbentuk akar pada umur 8 MST.

Berdasarkan hasil rekapitulasi sidik ragam, faktor perlakuan bahan organik nabati memiliki pengaruh yang sangat nyata terhadap semua peubah yang diamati yaitu persentase hidup, persentase kontaminasi, persentase $p l b s$ bermultiplikasi, jumlah daun, dan jumlah akar planlet anggrek Phalaenopsis amabilis. Sementara itu, perlakuan bahan organik hewani juga memiliki pengaruh yang nyata hampir terhadap semua peubah kecuali persentase $p l b s$ bermultipkasi dan jumlah akar pada saat 8 MST. Interaksi kedua faktor perlakuan juga berpengaruh sangat nyata hampir pada semua peubah yang diamati meliputi persentase $p l b s$ hidup spersentase $p l b s$ bermultiplikasi, jumlah daun dan jumlah akar.

\section{Persentase Hidup}

Kategori plbs yang hidup teramati dari plbs yang masih berwarna hijau. Persentase hidup plbs Phalaenopsis amabilis seperti terlihat pada Tabel 1. Persentase hidup plbs pada beberapa perlakuan mengalami penurunan pada setiap MST. Persentase plbs hidup pada 4 MST hampir mencapai $100 \%$ pada semua kombinasi perlakuan, kecuali pada media perlakuan bahan organik ubi jalar. Pada 8 MST, persentase hidup plbs paling tinggi adalah pada media kontrol, berbeda nyata persentase hidup plbs pada media dengan bahan organik ubi jalar. Penambahan emulsi ikan pada media kontrol dan media dengan penambahan bahan organik ekstrak kentang, tidak meningkatkan secara nyata persentase hidup plbs, sebaliknya pada media dengan bahan organik ekstrak pisang, persentase hidup plbs menurun secara nyata pada penambahan emulsi ikan 4 dan $6 \mathrm{ml} \mathrm{L}^{-1}$, dan pada media dengan penambahan ekstrak ubi jalar, persentase hidup plbs menurun pada pada penambahan emulsi ikan 2, 4 dan $6 \mathrm{ml} \mathrm{L}^{-1}$. Hal tersebut menunjukkan bahwa persentase hidup plbs pada perlakuan bahan organik ekstrak pisang dan ubi jalar cenderung menurun jika konsentrasi emulsi ikan ditingkatkan. Pola tersebut terlihat konsisten pada 12 dan 16 MST. Persentase hidup plbs paling tinggi pada 18 MST yaitu hampir mencapai 100\% diperoleh pada kontrol dengan penambahan emulsi ikan 2, 4 ataupun $6 \mathrm{ml} \mathrm{L}^{-1}$ dan media perlakuan ekstrak kentang tanpa emulsi ikan maupun dikombinasikan dengan emulsi 2 dan $4 \mathrm{ml} \mathrm{L}^{-1}$. Pemilihan media yang sesuai untuk mendapatkan persentase hidup plbs yang paling tinggi juga perlu mempertimbangkan biaya dan kepraktisan dalam penyediaan media, sehingga dalam percobaan ini media paling sederhana dan mudah dibuat adalah media dengan penambahan ekstrak kentang tanpa emulsi ikan atau media kontrol dengan penambahan emulsi ikan $2 \mathrm{ml} \mathrm{L}^{-1}$.

Kematian pada plbs terjadi karena adanya pelukaan pada plbs yang terjadi pada saat pemisahan plbs ke media perlakuan (subkultur). Hal tersebut sesuai dengan penelitian Murdad et al. (2006) yang menyatakan bahwa plbs yang baru disubkultur ke media baru akan mengalami pelukaan yang disebabkan oleh proses pemisahan yang memiliki peran penting dalam pembentukan plbs sekunder melalui proliferasi. Pelukaan tersebut dapat mendorong multiplikasi jumlah yang lebih tinggi dari jumlah plbs awal, tetapi juga menyebabkan kematian pada beberapa plbs yang terluka. Gejala kematian plbs ditunjukkan oleh adanya pencoklatan (browning). Browning disebabkan adanya pelukaan ketika pemisahan plbs sehingga menghasilkan fenol, lalu terjadi proses oksidasi fenol membentuk larutan berwarna coklat yang disebut quinon yang bersifat toksik, yang terakumulasi dalam media di sekitar plbs sehingga meracuni plbs (Syammiah, 2006). Menurut Syabana et al. (2015), akumulasi senyawa fenolik yang terkandung dalam tanaman kemudian teroksidasi akibat stres mekanik atau pelukaan 
pada eksplan. Senyawa fenol dihasilkan dari aktivitas enzim polifenol eksidase dan tirosinase. Dalam kondisi oksidatif akibat pelukaan, enzim tersebut secara alami disintesis oleh eksplan untuk mendorong sintesis fenol sebagai bentuk pertahanan diri, namun jika senyawa fenol berlebihan akan bersifat racun dan dapat merusak jaringan eksplan dan akhirnya menyebabkan kematian pada eksplan.

Menurut Murdad et al. (2006), respon awal pemisahan plbs adalah produksi eksudat fenolik dan browning pada medium di sekitar eksplan selama dua minggu pertama. Pengaruh negatif senyawa fenolik dapat dikurangi dengan penambahan arang aktif pada media, sehingga tidak menghambat pembengkakan bagian basal dari plbs untuk inisiasi plbs baru. Arang aktif secara signifikan juga dapat meningkatkan persen planlet hidup seperti yang dilaporkan Oktafiani et al. (2012), dimana persentase planlet hidup Phalaenopsis bellina pertumbuhan planlet terbaik diperoleh pada media Knudson PA $70 \%$ yang ditambahkan arang aktif. Hal ini menunjukkan bahwa penambahan arang aktif pada media menyebabkan planlet Phalaenopsis bellina dapat berkembang baik sedangkan planlet pada media yang tidak diberi tambahan arang aktif menunjukkan gejala fenolik, kematian jaringan sedikit demi sedikit dan akhirnya mati.

\section{Persentase Kontaminasi}

Salah satu kendala yang terjadi dalam kultur in vitro adalah adanya kontaminasi. Dalam penelitian ini, rata-rata persentase kontaminasi yang terjadi dari 4 MST hingga 16 MST berkisar antara 27-47\%. Pada saat 4 MST tercatat kontaminasi sebesar $27 \%$ pada media perlakuan $50 \mathrm{~g} \mathrm{~L}^{-1}$ ekstrak ubi jalar yang dikombinasikan dengan $4 \mathrm{ml} \mathrm{L}^{-1}$ emulsi ikan dan $40 \%$ pada media perlakuan $50 \mathrm{~g} \mathrm{~L}^{-1} \mathrm{ubi}$ jalar yang dikombinasikan dengan $6 \mathrm{ml} \mathrm{L}^{-1}$ emulsi ikan. Kontaminasi pada saat bulan pertama termasuk tinggi. Kontaminasi yang terjadi disebabkan oleh bakteri dan cendawan. Adanya kontaminasi tersebut terjadi karena beberapa hal seperti kondisi ruang kultur yang kurang steril, kesalahan prosedur yang dilakukan pada saat penanaman, dan proses pencucian alat kultur dan botol kultur yang mungkin kurang bersih.

Tabel 1. Rata-rata persentase hidup plbs anggrek Phalaenopsis amabilis pada perlakuan bahan organik nabati dan hewani.

\begin{tabular}{|c|c|c|c|c|}
\hline \multirow{2}{*}{ Perlakuan } & \multicolumn{4}{|c|}{ Emulsi Ikan $\left(\mathrm{ml} \mathrm{L}^{-1}\right)$} \\
\hline & 0 & 2 & 4 & 6 \\
\hline & & . & & \\
\hline Kontrol & 99 a & $100 \mathrm{a}$ & $100 \mathrm{a}$ & $100 \mathrm{a}$ \\
\hline $50 \mathrm{~g} \mathrm{~L}^{-1}$ pisang & $100 \mathrm{a}$ & $99 \mathrm{a}$ & $99 \mathrm{a}$ & $84 \mathrm{ab}$ \\
\hline $50 \mathrm{~g} \mathrm{~L}^{-1}$ kentang & $99 \mathrm{a}$ & $100 \mathrm{a}$ & $100 \mathrm{a}$ & 99 a \\
\hline $50 \mathrm{~g} \mathrm{~L}^{-1}$ ubi jalar & $85 \mathrm{ab}$ & $100 \mathrm{a}$ & $71 \mathrm{bc}$ & $59 \mathrm{c}$ \\
\hline Kontrol & $95 \mathrm{ab}$ & $93 \mathrm{abc}$ & $100 \mathrm{a}$ & $\begin{array}{l}\ldots \ldots \ldots \\
83 a b c\end{array}$ \\
\hline $50 \mathrm{~g} \mathrm{~L}^{-1}$ pisang & $91 \mathrm{abc}$ & $87 \mathrm{abc}$ & $69 \mathrm{cde}$ & $51 \mathrm{efg}$ \\
\hline $50 \mathrm{~g} \mathrm{~L}^{-1}$ kentang & $84 a b c$ & $91 \mathrm{abc}$ & $96 \mathrm{ab}$ & 73 bcde \\
\hline $50 \mathrm{~g} \mathrm{~L}^{-1}$ ubi jalar & 77 abcd & $56 \mathrm{def}$ & $32 \mathrm{~g}$ & $37 \mathrm{fg}$ \\
\hline Kontrol & $85 \mathrm{abc}$ & $100 \mathrm{a}$ & $\begin{array}{l}\ldots \ldots \ldots \\
100 \mathrm{a}\end{array}$ & 99 a \\
\hline $50 \mathrm{~g} \mathrm{~L}^{-1}$ pisang & $100 \mathrm{a}$ & $100 \mathrm{a}$ & $100 \mathrm{a}$ & $37 \mathrm{e}$ \\
\hline $50 \mathrm{~g} \mathrm{~L}^{-1}$ kentang & $100 \mathrm{a}$ & $100 \mathrm{a}$ & $96 \mathrm{ab}$ & $77 \mathrm{c}$ \\
\hline $50 \mathrm{~g} \mathrm{~L}^{-1}$ ubi jalar & $87 \mathrm{abc}$ & $81 \mathrm{bc}$ & $53 \mathrm{~d}$ & $59 \mathrm{~d}$ \\
\hline Kontrol & $81 \mathrm{bc}$ & $92 \mathrm{ab}$ & $\begin{array}{c}\ldots \ldots \ldots \\
100 \mathrm{a}\end{array}$ & 98 a \\
\hline $50 \mathrm{~g} \mathrm{~L}^{-1}$ pisang & $97 \mathrm{ab}$ & $93 \mathrm{ab}$ & $75 \mathrm{c}$ & $32 \mathrm{e}$ \\
\hline $50 \mathrm{~g} \mathrm{~L}^{-1}$ kentang & $100 \mathrm{a}$ & $100 \mathrm{a}$ & $94 \mathrm{ab}$ & $75 \mathrm{c}$ \\
\hline $50 \mathrm{~g} \mathrm{~L}^{-1}$ ubi jalar & $85 a b c$ & $70 \mathrm{c}$ & $50 \mathrm{~d}$ & $49 \mathrm{~d}$ \\
\hline
\end{tabular}

Keterangan: Angka-angka yang disertai huruf yang sama pada waktu pengamatan yang sama pada baris atau kolom tidak berbeda nyata berdasarkan uji Duncan's Multiple Range Test (DMRT) pada taraf $\alpha=5 \%$. 
Yusnita (2007), menyatakan bahwa pencucian botol yang kurang sempurna menyebabkan kontaminasi bakteri atau cendawan pada dinding botol yang biasanya terjadi beberapa minggu atau bulan setelah media disterilkan. Kontaminasi dapat berasal dari mikroba bakteri atau spora cendawan yang masih bertahan hidup yang mungkin terdapat dalam esktrak bahan organik, meskipun telah di sterilisasi dengan autoklaf.

\section{Persentase Multiplikasi}

Multiplikasi merupakan kemampuan eksplan untuk memperbanyak diri (Nazi, 2014). Plbs Phalaenopsis amabilis mulai terlihat bermultiplikasi pada saat 6 MST hingga 10 MST. Hasil analisis statistik menunjukkan bahwa faktor bahan organik nabati dan interaksinya dengan emulsi ikan berpengaruh sangat nyata terhadap persentase plbs Phalaenopsis amabilis yang bermultiplikasi seperti disajikan pada Tabel 2 .

Persentase plbs Phalaenopsis amabilis yang bermultiplikasi secara umum meningkat dengan bertambahnya minggu pengkulturan (6-10 MST), dengan persentase plbs yang bermultiplikasi berkisar 16-77\%, seperti terlihat pada Tabel 2. Ekstrak bahan organik nabati terlihat lebih berpengaruh dibandingkan emulsi ikan terhadap persentase plbs bermultiplikasi. Persentase plbs yang bermultiplikasi pada media kontrol hingga 10 MST hanya sebesar $41 \%$, sedangkan media dengan perlakuan ekstrak kentang atau ekstrak pisang lebih baik (berkisar 60-77\%). Sebaliknya pada media dengan perlakuan ekstrak ubi jalar (berkisar 40-67\%). Penambahan emulsi ikan pada media kontrol dan perlakuan bahan organik ekstrak kentang sebaiknya tidak lebih dari $4 \mathrm{ml} \mathrm{L}^{-1}$, pada media dengan bahan organik esktrak pisang tidak lebih dari $2 \mathrm{ml} \mathrm{L}^{-1}$, karena pada konsentrasi emulsi ikan yang lebih tinggi persentase plbs bermultiplikasi akan menurun. Sebaliknya, pada media perlakuan ekstrak ubi jalar, peningkatan konsentrasi emulsi ikan hingga 6 $\mathrm{ml} \mathrm{L}^{-1}$ masih dapat meningkatkan persentase plbs bermultiplikasi. Hal ini kemungkinan disebabkan emulsi ikan dapat menyuplai nutrisi terutama yang tidak terkandung dalam esktrak ubi jalar yang dapat mendorong multiplikasi plbs.

Perbedaan bahan organik mempengaruhi pertumbuhan dan multiplikasi plbs karena perbedaan kandungan nutrisi, gula, asam amino, vitamin maupun sifat fisik media yang ditimbulkan oleh bahan organik tertentu. Ekstrak kentang dan pisang menunjukkan pengaruh yang lebih baik dibanding ekstrak ubi jalar.

Tabel 2. Rata-rata persentase plbs bermultiplikasi pada anggrek Phalaenopsis amabilis pada perlakuan bahan organik nabati dan hewani.

\begin{tabular}{|c|c|c|c|c|}
\hline \multirow{2}{*}{ Perlakuan } & \multicolumn{4}{|c|}{ Emulsi Ikan $\left(\mathrm{ml} \mathrm{L}^{-1}\right)$} \\
\hline & 0 & 2 & 4 & 6 \\
\hline & \multicolumn{4}{|c|}{ 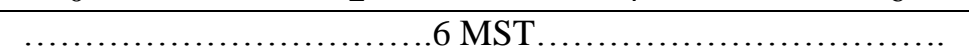 } \\
\hline Kontrol & 28 cde & $48 \mathrm{abc}$ & $47 \mathrm{abcd}$ & $49 \mathrm{abc}$ \\
\hline $50 \mathrm{~g} \mathrm{~L}^{-1}$ pisang & $55 \mathrm{ab}$ & 39 abcd & $25 \mathrm{de}$ & $15 \mathrm{e}$ \\
\hline $50 \mathrm{~g} \mathrm{~L}^{-1}$ kentang & $61 \mathrm{a}$ & $56 \mathrm{ab}$ & $59 \mathrm{ab}$ & $56 \mathrm{ab}$ \\
\hline \multirow[t]{2}{*}{$50 \mathrm{~g} \mathrm{~L}^{-1}$ ubi jalar } & 36 bcde & $51 \mathrm{ab}$ & 28 cde & $49 \mathrm{abc}$ \\
\hline & \multicolumn{4}{|c|}{ 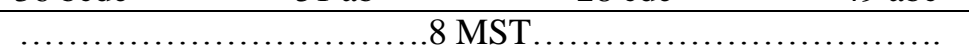 } \\
\hline Kontrol & 39 ef & $67 a b c$ & $68 \mathrm{abc}$ & 59 abcde \\
\hline $50 \mathrm{~g} \mathrm{~L}^{-1}$ pisang & $71 \mathrm{ab}$ & 49 bcdef & 41 ef & $16 \mathrm{~g}$ \\
\hline $50 \mathrm{~g} \mathrm{~L}^{-1}$ kentang & 64 abcd & 60 abcde & $77 \mathrm{a}$ & 57 abcde \\
\hline \multirow[t]{2}{*}{$50 \mathrm{~g} \mathrm{~L}^{-1}$ ubi jalar } & 44 def & $47 \mathrm{cdef}$ & $35 \mathrm{fg}$ & $67 \mathrm{abc}$ \\
\hline & \multicolumn{4}{|c|}{.........10 MST } \\
\hline Kontrol & 41 ef & $68 \mathrm{abc}$ & $73 \mathrm{ab}$ & 56 bcdef \\
\hline $50 \mathrm{~g} \mathrm{~L}^{-1}$ pisang & $69 \mathrm{abc}$ & $63 \mathrm{abc}$ & $39 \mathrm{f}$ & $16 \mathrm{~g}$ \\
\hline $50 \mathrm{~g} \mathrm{~L}^{-1}$ kentang & $68 \mathrm{abc}$ & $61 \mathrm{abcd}$ & $77 \mathrm{a}$ & 59 abcde \\
\hline $50 \mathrm{~g} \mathrm{~L}^{-1}$ ubi jalar & $43 \mathrm{def}$ & $40 \mathrm{ef}$ & $53 \mathrm{cdef}$ & $67 \mathrm{abc}$ \\
\hline
\end{tabular}

Keterangan: Angka-angka yang disertai huruf yang sama pada waktu pengamatan yang sama pada baris atau kolom tidak berbeda nyata berdasarkan uji Duncan's Multiple Range Test (DMRT) pada taraf $\alpha=5 \%$. 
Penelitian Chai et al. (2002) menyatakan bahwa jumlah plbs baru pada anggrek Phalaenopsis terbentuk lebih banyak pada media dengan penambahan $100 \mathrm{~g} \mathrm{~L}^{-1}$ ekstrak kentang dibandingkan dengan dua media lain yaitu penambahan $100 \mathrm{~g} \mathrm{~L}^{-1}$ ekstrak apel dan penambahan $50 \mathrm{~g} \mathrm{~L}^{-1}$ ekstrak apel + $50 \mathrm{~g} \mathrm{~L}^{-1}$ ekstrak kentang. Bahan lain yang berpengaruh terhadap multiplikasi plbs adalah arang aktif dan air kelapa pada media. Murdad et al. (2006) menyatakan bahwa arang aktif secara signifikan meningkatkan persentase multiplikasi plbs. Widiastoety et al. (2009) juga menyatakan bahwa air kelapa dapat merangsang pembelahan sel dan menstimulir proses diferensiasi, serta pembentukan plbs. Namun dalam penelitian ini, penambahan ekstrak kentang atau ubi jalar atau emulsi ikan 2-4 $\mathrm{ml} \mathrm{L}^{-1}$ dalam media kontrol yang sudah mengandung air kelapa dapat meningkatkan multiplikasi plbs.

\section{Jumlah Daun}

Plbs akan tumbuh menjadi planlet diawali dengan munculnya daun dan diikuti akar. Rata-rata pertambahan jumlah daun dipengaruhi oleh perlakuan bahan organik nabati, hewani, dan interaksi antara bahan organik nabati dan hewani (Tabel 3). Pada 16 MST, perlakuan ekstrak kentang $50 \mathrm{~g} \mathrm{~L}^{-1}$ tanpa penambahan emulsi ikan menghasilkan jumlah daun terbanyak yaitu 3.16 helai, sebaliknya jumlah daun terendah dihasilkan pada perlakuan media $50 \mathrm{~g} \mathrm{~L}^{-1}$ pisang $+6 \mathrm{ml} \mathrm{L}^{-1}$ emulsi ikan yaitu 1.27 daun. Jumlah daun pada media kontrol dapat ditingkatkan dengan penambahan $2 \mathrm{ml} \mathrm{L}^{-1}$ emulsi ikan, sebaliknya pada media perlakuan ekstrak pisang, penambahan emulsi ikan tidak berpengaruh nyata terhadap jumlah daun. Pada media perlakuan esktrak ubi jalar, perlakuan emulsi ikan cenderung belum konsisten pengaruhnya terhadap jumlah daun planlet. Secara ekonomis, media perlakuan ekstrak kentang tanpa emulsi ikan sudah optimum untuk mendapatkan jumlah daun terbanyak.

Tabel 3. Rata-rata jumlah daun planlet anggrek Phalaenopsis amabilis pada perlakuan bahan organik nabati dan hewani.

\begin{tabular}{|c|c|c|c|c|}
\hline \multirow{2}{*}{ Perlakuan } & \multicolumn{4}{|c|}{ Emulsi Ikan $\left(\mathrm{ml} \mathrm{L}^{-1}\right)$} \\
\hline & 0 & 2 & 4 & 6 \\
\hline & \multicolumn{4}{|c|}{ Jumlah Daun (helai) pada 4 MST. } \\
\hline Kontrol & 0.2 bcde & $0.3 \mathrm{bcd}$ & $0.4 \mathrm{abc}$ & 0.2 bcde \\
\hline $50 \mathrm{~g} \mathrm{~L}^{-1}$ pisang & $0.4 \mathrm{ab}$ & $0.5 \mathrm{a}$ & $0.2 \mathrm{def}$ & $0.0 \mathrm{f}$ \\
\hline $50 \mathrm{~g} \mathrm{~L}^{-1}$ kentang & 0.2 bcde & 0.2 cdef & $0.0 \mathrm{f}$ & $0.0 \mathrm{f}$ \\
\hline \multirow[t]{2}{*}{$50 \mathrm{~g} \mathrm{~L}^{-1}$ ubi jalar } & $0.1 \mathrm{def}$ & $0.0 \mathrm{f}$ & $0.2 \mathrm{cdef}$ & $0.1 \mathrm{ef}$ \\
\hline & \multicolumn{4}{|c|}{..................Jumlah Daun (helai) pada 8 MST..................... } \\
\hline Kontrol & $0.7 \mathrm{cdef}$ & $0.9 \mathrm{bcd}$ & $0.8 \mathrm{cde}$ & $0.8 \mathrm{cdef}$ \\
\hline $50 \mathrm{~g} \mathrm{~L}^{-1}$ pisang & $1.1 \mathrm{~b}$ & $1.1 \mathrm{bc}$ & 0.7 def & $0.6 \mathrm{def}$ \\
\hline $50 \mathrm{~g} \mathrm{~L}^{-1}$ kentang & $1.5 \mathrm{a}$ & $1.0 \mathrm{bc}$ & $0.6 \mathrm{def}$ & $0.5 \mathrm{ef}$ \\
\hline \multirow[t]{2}{*}{$50 \mathrm{~g} \mathrm{~L}^{-1}$ ubi jalar } & $0.7 \mathrm{def}$ & $0.1 \mathrm{~g}$ & 0.7 cdef & $0.4 \mathrm{fg}$ \\
\hline & \multicolumn{4}{|c|}{..................Jumlah Daun (helai) pada 12 MST. } \\
\hline Kontrol & $0.9 \mathrm{gh}$ & $1.5 \mathrm{bcd}$ & $1.2 \mathrm{cdefg}$ & $1.1 \mathrm{efg}$ \\
\hline $50 \mathrm{~g} \mathrm{~L}^{-1}$ pisang & $1.3 \mathrm{cdef}$ & 1.4 cde & $0.7 \mathrm{~h}$ & $0.7 \mathrm{~h}$ \\
\hline $50 \mathrm{~g} \mathrm{~L}^{-1}$ kentang & $2.1 \mathrm{a}$ & $1.8 \mathrm{ab}$ & $1.6 \mathrm{bc}$ & 1.4 cde \\
\hline \multirow[t]{2}{*}{$50 \mathrm{~g} \mathrm{~L}^{-1}$ ubi jalar } & $1.1 \mathrm{defg}$ & $0.9 \mathrm{gh}$ & $1.3 \mathrm{cdef}$ & $1.0 \mathrm{fgh}$ \\
\hline & \multicolumn{4}{|c|}{....................Jumlah Daun (helai) pada 16 MST..................... } \\
\hline Kontrol & $1.6 \mathrm{fg}$ & $2.7 \mathrm{bc}$ & 1.9 ef & $1.9 \mathrm{ef}$ \\
\hline $50 \mathrm{~g} \mathrm{~L}^{-1}$ pisang & $2.1 \mathrm{de}$ & $2.3 \mathrm{cde}$ & $1.6 \mathrm{fg}$ & $1.3 \mathrm{~g}$ \\
\hline $50 \mathrm{~g} \mathrm{~L}^{-1}$ kentang & $3.2 \mathrm{a}$ & $2.8 \mathrm{ab}$ & $2.6 \mathrm{bcd}$ & 2.2 cde \\
\hline $50 \mathrm{~g} \mathrm{~L}^{-1}$ ubi jalar & $2.0 \mathrm{ef}$ & $1.9 \mathrm{ef}$ & 2.4 bcde & $1.9 \mathrm{ef}$ \\
\hline
\end{tabular}


Perlakuan media ekstrak kentang $50 \mathrm{~g} \mathrm{~L}^{-1}$ tanpa emulsi ikan menunjukkan jumlah daun terbanyak, diduga karena peranan dari bahan organik kentang yang ditambahkan sehingga walaupun tanpa emulsi ikan tetapi kebutuhan unsur-unsur kemungkinan telah terpenuhi dari penambahan bahan organik kentang. Hal tersebut sesuai dengan penelitian yang dilakukan oleh Silviasari (2010), rata-rata jumlah daun anggrek Dendrobium alice noda $x$ Dendrobium tomie terbanyak dihasilkan pada media tanpa penambahan emulsi ikan. Selain itu, hasil penelitian yang dilakukan oleh Syammiah (2006) menunjukkan bahwa penggunaan $15 \%$ jus kentang pada media Knudson $\mathrm{C}$ merupakan media tercepat untuk pertumbuhan plbs anggrek Dendrobium Bertacong Blue $x$ Dendrobium undulatum dibandingkan dengan penambahan $5 \%$ jus tomat dan 5\% jus lidah buaya.

Perlakuan media dengan perlakuan ekstrak ubi jalar memiliki rata-rata jumlah daun terendah. Hal yang serupa dilaporkan oleh Widiastoety dan Purbadi (2003) pada kultur anggrek Oncidium, dimana, penambahan 15.9 g karbohidrat yang berasal dari bubur ubi jalar baik varietas berdaging putih, merah, maupun ungu yang mengandung gula berkisar antara 2.0-6.7\% diduga menyebabkan pertumbuhan jumlah dan luas daun planlet terhambat. Penghambatan tersebut diduga disebabkan oleh pengaruh tekanan osmotik akibat penggunaan sumber karbohidrat dengan konsentrasi yang sangat tinggi.

Pada Tabel 3 terlihat bahwa semakin tinggi konsentrasi emulsi ikan yang diberikan maka jumlah daun yang dihasilkan cenderung semakin sedikit. Hal tersebut diduga terjadi karena emulsi ikan menyumbang unsur nitrogen dan thiamin. Tiamin selain diperoleh dari media dasar juga terdapat pada bahan organik nabati seperti pisang, kentang, ubi jalar, emulsi ikan, dan air kelapa. Menurut Widiastoety et al. (2009), terjadinya akumulasi thiamin menyebabkan proses proses pertumbuhan dan perkembangan jaringan tanaman mengalami hambatan.

\section{Jumlah Akar}

Akar merupakan bagian terpenting dari tanaman karena berkaitan dengan kelangsungan hidup tanaman. Jumlah akar pada tanaman mengindikasikan seberapa luas jangkauan tanaman dalam menyerap nutrisi dan unsur hara. Semakin banyak jumlah akar maka semakin luas jangkauan tanaman tersebut dan semakin banyak hara yang diserap oleh tanaman (Silviasari, 2010). Dalam penelitian ini, sampai 4 MST, planlet belum menghasilkan akar dan akar baru mulai terbentuk pada saat plbs berumur 8 MST.

Perlakuan $50 \mathrm{~g} \mathrm{~L} \mathrm{~L}^{-1}$ ekstrak kentang tanpa emulsi ikan menghasilkan rata-rata jumlah akar terbanyak dibandingkan ekstrak pisang ataupun ubi jalar (Tabel 4). Rata-rata jumlah akar pada media perlakuan ekstrak kentang tersebut adalah 2.2 akar. Rata-rata jumlah akar terendah dihasilkan pada media kontrol sebanyak 0.7 akar. Perlakuan ekstrak pisang ditambah $2 \mathrm{ml} \mathrm{L}^{-1}$ emulsi ikan memiliki pengaruh yang nyata lebih tinggi dibandingkan perlakuan ekstrak ubi jalar ditambah $2 \mathrm{ml} \mathrm{L}^{-1}$ emulsi ikan. Penambahan emulsi ikan hanya dimungkinkan pada konsentrasi $2 \mathrm{ml} \mathrm{L}^{-1}$, karena peningkatan konsentrasi emulsi ikan menjadi 4 atau $6 \mathrm{ml} \mathrm{L}^{-1}$ cenderung menekan jumlah akar. Menurut Sallolo et al. (2012), emulsi ikan selain mengandung unsur nitrogen (N) dan kalium (K) juga mengandung unsur fosfor (P) yang penting untuk perakaran. Penambahan arang aktif pada media juga mempengaruhi pertumbuhan akar. Eymar et al. (2000) mengamati bahwa penambahan arang aktif meningkatkan dan mempertahankan tingkat $\mathrm{pH}$ selama kultur, meningkatkan serapan nitrogen, dan meningkatkan pertumbuhan dan aspek visual dari eksplan serta mengurangi efek penghambatan sitokinin eksogen pada pertumbuhan akar.

Berdasarkan Tabel 4 terlihat bahwa semakin tinggi konsentrasi emulsi ikan yang diberikan maka jumlah akar yang dihasilkan juga cenderung semakin sedikit pada semua perlakuan ekstrak bahan organik nabati. Hal tersebut sesuai dengan penelitian yang dilakukan oleh Silviasari (2010) yang diduga terjadi karena kandungan asam amino triptofan pada emulsi ikan. Asam amino ini dapat membantu tanaman membentuk auksin endogen sehingga konsentrasi auksin semakin tinggi. Konsentrasi auksin yang tinggi dapat menghambat pembelahan dan regenerasi sel tanaman. Auksin yang terdapat pada emulsi ikan adalah IAA (Indole acetic acid), IAA terbentuk dari asam amino triptofan. Konsentrasi IAA yang relatif tinggi pada akar, akan menyebabkan terhambatnya perpanjangan akar (Zainal, 1994). 
Tabel 4. Rata-rata jumlah akar planlet anggrek Phalaenopsis amabilis pada perlakuan bahan organik nabati dan hewani.

\begin{tabular}{|c|c|c|c|c|}
\hline \multirow{2}{*}{ Perlakuan } & \multicolumn{4}{|c|}{ Emulsi Ikan $\left(\mathrm{ml} \mathrm{L}^{-1}\right)$} \\
\hline & 0 & 2 & 4 & 6 \\
\hline & \multicolumn{4}{|c|}{ Jumlah Akar pada 8 MST.. } \\
\hline Kontrol & $0.0 \mathrm{~b}$ & $0.1 \mathrm{ab}$ & $0.0 \mathrm{~b}$ & $0.0 \mathrm{~b}$ \\
\hline $50 \mathrm{~g} \mathrm{~L}^{-1}$ pisang & $0.1 \mathrm{ab}$ & $0.0 \mathrm{~b}$ & $0.2 \mathrm{a}$ & $0.0 \mathrm{~b}$ \\
\hline $50 \mathrm{~g} \mathrm{~L}^{-1}$ kentang & $0.0 \mathrm{~b}$ & $0.0 \mathrm{~b}$ & $0.0 \mathrm{~b}$ & $0.0 \mathrm{~b}$ \\
\hline \multirow[t]{2}{*}{$50 \mathrm{~g} \mathrm{~L}^{-1}$ ubi jalar } & $0.0 \mathrm{~b}$ & $0.0 \mathrm{~b}$ & $0.0 \mathrm{~b}$ & $0.0 \mathrm{~b}$ \\
\hline & \multicolumn{4}{|c|}{ Jumlah Akar pada 12 MST. } \\
\hline Kontrol & $0.3 \mathrm{ef}$ & $0.6 \mathrm{bcd}$ & $0.4 \mathrm{cdef}$ & 0.4 cdef \\
\hline $50 \mathrm{~g} \mathrm{~L}^{-1}$ pisang & $0.6 \mathrm{bcd}$ & $0.5 \mathrm{cde}$ & 0.2 ef & 0.3 cdef \\
\hline $50 \mathrm{~g} \mathrm{~L}^{-1}$ kentang & $1.3 \mathrm{a}$ & $1.0 \mathrm{~b}$ & $0.7 \mathrm{bc}$ & $0.5 \mathrm{cde}$ \\
\hline \multirow[t]{2}{*}{$50 \mathrm{~g} \mathrm{~L}^{-1}$ ubi jalar } & $0.3 \mathrm{ef}$ & $0.1 \mathrm{f}$ & $0.3 \mathrm{def}$ & $0.2 \mathrm{ef}$ \\
\hline & \multicolumn{4}{|c|}{.Jumlah Akar pada 16 MST.. } \\
\hline Kontrol & $0.7 \mathrm{f}$ & $1.4 \mathrm{bc}$ & $1.0 \mathrm{def}$ & $1.0 \mathrm{def}$ \\
\hline $50 \mathrm{~g} \mathrm{~L}^{-1}$ pisang & $1.4 \mathrm{bc}$ & $1.2 \mathrm{cde}$ & $0.8 \mathrm{ef}$ & $0.7 \mathrm{f}$ \\
\hline $50 \mathrm{~g} \mathrm{~L}^{-1}$ kentang & $2.2 \mathrm{a}$ & $1.6 \mathrm{~b}$ & $1.4 \mathrm{bc}$ & $1.2 \mathrm{~cd}$ \\
\hline $50 \mathrm{~g} \mathrm{~L}^{-1}$ ubi jalar & $0.9 \mathrm{def}$ & $0.8 \mathrm{f}$ & $1.0 \mathrm{def}$ & $0.8 \mathrm{ef}$ \\
\hline
\end{tabular}

Keterangan: Angka-angka yang disertai huruf yang sama pada waktu pengamatan yang sama pada baris atau kolom tidak berbeda nyata berdasarkan uji Duncan's Multiple Range Test (DMRT) pada taraf $\alpha=5 \%$.

Berdasarkan hasil penelitian ini, terlihat bahwa bahan organik ekstrak kentang atau pisang dan emulsi ikan pada konsentrasi tertentu berpengaruh baik terhadap pertumbuhan dan morfogenesis plbs. Bahan organik tersebut menyumbang gula, asam amino, unsur-unsur hara tanaman seperti $\mathrm{N}, \mathrm{P}$ dan $\mathrm{K}$ dan senyawa organik kompleks lainnya. Hasil penelitian ini menunjukkan bahwa peubah-peubah yang diamati menunjukkan nilai tertinggi pada perlakuan media yang tidak selalu sama. Peubah persentase hidup plbs tertinggi diperoleh pada media dengan penambahan emulsi ikan 2, 4 ataupun $6 \mathrm{ml} \mathrm{L}^{-1}$ dan media perlakuan ekstrak kentang atau pisang tanpa emulsi ikan maupun dikombinasikan dengan emulsi 2 atau $4 \mathrm{ml} \mathrm{L}^{-1}$, dengan persentase $p l b s$ hidup di media-media tersebut di atas $90 \%$. Plbs yang mengalami multiplikasi terbaik diperoleh pada media perlakuan emulsi ikan $2 \mathrm{ml} \mathrm{L}^{-1}$ atau media perlakuan ekstrak pisang atau kentang, untuk esktrak pisang dapat dikombinasikan dengan emulsi ikan 2 atau $4 \mathrm{ml} \mathrm{L}^{-1}$, sedangkan untuk ekstrak kentang dapat dikombinasikan dengan 2, 4, atau $6 \mathrm{ml} \mathrm{L}^{-1}$ emulsi ikan, dengan persentase plbs bermultiplikasi sekitar 60$70 \%$. Media perlakuan esktrak ubi jalar kurang sesuai untuk multiplikasi plbs. Sementara itu, untuk peubah jumlah daun dan akar paling banyak dihasilkan pada media perlakuan ekstrak kentang tanpa penambahan emulsi ikan, menunjukkan bahwa media tersebut sesuai untuk morfogenesis plbs menjadi planlet dan perkembangan organ daun dan akar planlet secara maksimal. Jika mempertimbangkan aspek kepraktisan dan ekonomi, hasil penelitian ini menyarankan bahwa untuk tahapan pertumbuhan dan multiplikasi plbs, media yang paling sesuai adalah media kontrol dengan penambahan emulsi ikan $2 \mathrm{ml} \mathrm{L}^{-1}$ atau media dengan perlakuan ekstrak pisang atau ekstrak kentang tanpa emulsi ikan, selanjutnya untuk morfogenesis planlet plbs dapat dipindah ke media perlakuan ekstrak kentang.

\section{KESIMPULAN}

Media perlakuan terbaik untuk pertumbuhan dan multiplikasi plbs adalah media kontrol yang dikombinasikan dengan emulsi ikan $2 \mathrm{ml} \mathrm{L}^{-1}$ atau media perlakuan ekstrak pisang atau ekstrak kentang tanpa penambahan emulsi ikan, yang dapat menghasilkan persentase hidup plbs di atas 90\% dan persen plbs bermultiplikasi sekitar 70\%. Morfogenesis plbs menjadi planlet yang sempurna terlihat dari jumlah daun dan akar terbanyak dihasilkan pada perlakuan ekstrak kentang tanpa emulsi ikan dengan jumlah daun 
dan akar yang dihasilkan adalah sebanyak 3.2 helai daun dan 2.2 akar.

\section{SARAN}

Kultur plbs pada tahap multiplikasi sebaiknya menggunakan media dengan penambahan emulsi ikan $2 \mathrm{ml} \mathrm{L}^{-1}$ dan untuk pembesaran planlet menggunakan media dengan penambahan ekstrak kentang tanpa penambahan emulsi ikan. Pertumbuhan lanjut planlet pada tahap aklimatisasi perlu dievaluasi untuk mengetahui kualitas planlet dari berbagai asal media perlakuan.

\section{UCAPAN TERIMA KASIH}

Penelitian ini didanai oleh Direktorat Jenderal Pendidikan Tinggi, Kementrian Riset dan Teknologi melalui skema Riset Hibah Kompentensi tahun 2016 atas nama Dr. Dewi Sukma, SP. MSi, dengan nomor kontrak: 079/SP2H/LT/DRPM/II/2016.

\section{DAFTAR PUSTAKA}

Agriani, S.M. 2010. Pengaruh konsentrasi ekstrak ubi jalar dan emulsi ikan terhadap pertumbuhan plb anggrek persilangan Phalaenopsis 'Pinlong Cinderella' $x$ Vanda tricolor pada media Knudson C. [Skripsi]. Universitas Sebelas Maret. Surakarta.

Andini, N. 2013. Pertumbuhan protocorm like bodies (plbs) dua populasi hasil persilangan anggrek Phalaenopsis pada beberapa komposisi media. [Skripsi]. Institut Pertanian Bogor. Bogor.

Chai, M.L., C.J. Xu, K.K. Senthil, J.Y. Kim, D.H. Kim. 2002. Stable transformation of protocorm like bodies in Phalaenopsis orchid mediated by Agrobacterium tumefaciens. Sci. Hort. 96(2002): 213-224.

Dwiarum, A.C. 2007. Pengaruh kombinasi media kultur in vitro dengan penambahan bahan organik terhadap pertumbuhan protocorm like bodies (plb) anggrek Pharaphalaenopsis serpentilingua. [Skripsi]. Institut Pertanian Bogor. Bogor.

Eymar, E., J. Alegre, , M. Toribio, D. Lopezvlla. 2000. Effect of activated charcoal and 6-benzyladenine on in vitro nitrogen uptake by Lagerstroemia indica. Plant Cell Tissue Organ Cult. 63: 57-65.

Kasutjianingati, R. Irawan. 2013. Media alternatif perbanyakan in vitro anggrek bulan (Phalaenopsis amabilis). J. Agroteknos. 3(3): 184-189.

Murashige, T., F. Skoog.1962. A revised medium for rapid growth and bioassays with tobacco tissue cultures. Physiologia Plantarum. 15: 473-497.

Murdad, R., K.S, Hwa, C.K. Seng, M.A. Latip, Z.A. Aziz, R. Ripin. 2006. High frequency multiplication of Phalaenopsis gigantea using trimmed bases protocorm technique. Sci. Hort. 111: 73-79.

Nazi. 2014. Kultur protocorm like bodies anggrek hasil persilangan Phalaenopsis gigantea $x$ Phalaenopsis violacea pada beberapa kombinasi media dan ZPT. Skripsi. Institut Pertanian Bogor. Bogor.

Niedz R.P., T.J Evens. 2007. Regulating plant in vitro growth by mineral nutrition. In Vitro Cell. Dev. Biol. Plant. 43: 370381.

Oktafiani, A., M. Puspitasari, T. Purbiati, Destiwarni. 2012. Pengaruh beberapa media kultur jaringan terhadap pertumbuhan planet anggrek Phalaenopsis bellina. Balai Pengkajian Teknologi Pertanian. Kalimantan Barat.

Putri, H.A. 2015. Pengaruh komposisi media dasar dan kitosan terhadap pertumbuhan protocorm like bodies (plbs) dan planlet anggrek Phalaenopsis hibrida. [Skripsi]. Institut Pertanian Bogor. Bogor. 
Raynalta, E., D. Sukma. 2013. Pengaruh komposisi media dalam perbanyakan protocorm like bodies, pertumbuhan planlet, dan aklimatisasi Phalaenopsis amabilis J. Hort. Indonesia. 4(3): 131139

Rukmana, R. 2000. Anggrek Bulan. Kanisius. Yogyakarta.

Sallolo, S.T., I.G.R. Sadimantara, T. Wijayanto. 2012. Pertumbuhan anggrek Dendrobium Candy Stripe Lasianthera pada media sapih Vacin dan Went secara in vitro dengan penambahan ekstrak pisang raja dan fish emulsion. J. Penelitian Agronomi. 1(1): 57-62.

Sandra, E. 2012. Cara Mudah Memahami dan Menguasai Kultur Jaringan Skala Rumah Tangga. IPB Press. Bogor.

Semiarti, E., A. Indiarto, E.A. Suyono, R.L. Nurwulan, R. Restiani. 2010. Mikropropagasi tanaman anggrek hitam Coelogyne pandurata Lindl. dengan penyisipan gen penumbuh tunas melalui Agrobacterium. Seminar Nasional Biologi UGM; Yogyakarta, 24-25 September 2010.

Silviasari, A.D. 2010. Pengaruh konsentrasi ekstrak ubi jalar dan emulsi ikan terhadap pertumbuhan planlet anggrek Dendrobium alice noda x Dendrobium tomie dan Phalaenopsis pinlong Cinderella $x$ Vanda tricolor pada medium Vacin dan Went. [Skripsi]. Universitas Sebelas Maret. Surakarta.
Syabana, M.A., I. Rohmawati, E.P. Ningsih. 2015. Pertumbuhan tanaman marasi (Cuculigo latifolia) dengan perbedaan konsentrasi NAA (Naphthalene Acetic Acid) dan BAP (Benzyl Amino Purine) secara in vitro. Jur. Agroekotek. 7(1): 615.

Syammiah. 2006. Jenis senyawa organik suplemen pada medium Knudson $C$ untuk pertumbuhan protocorm like bodies Dendrobium bertacong blue $\mathrm{x}$ Dendrobium undulatum. J. Floratek. 2: 86-92.

Widiastoety, D., Purbadi. 2003. Pengaruh bubur ubikayu dan ubijalar terhadap pertumbuhan plantlet anggrek Dendrobium. J. Hort. 13(1): 1-6.

Widiastoety, D., N. Solvia, S. Kartikaningrum. 2009. Pengaruh tiamin terhadap pertumbuhan planlet anggrek Oncidium secara in vitro. J. Hort. 19(1): 35-39.

Yusnita, C. Kesuma, D. Andiviaty, S. Ramadiana, D. Hapsoro. 2007. Perbanyakan klonal Phalaenopsis sp. in vitro dari eksplan daun dan eksplan tangkai bunga. Hal 119-124. Prosiding Seminar Nasional Hasil Penelitian yang Dibiayai oleh Hibah Kompetitif. Bogor, 1-2 Agustus 2007.

Zainal, A. 1994. Dasar-dasar Pengetahuan tentang Zat Pengatur Tumbuh. Angkasa, Bandung. 